\title{
A kis dózisú komputertomográfiával történő tüdőrákszürés költségvetési hatása
}

\author{
Nagy Balázs dr. ${ }^{1,2}$ - Szilbehorn Lászlón ${ }^{1,3}$ - Kerpel-Fronius Anna dr. ${ }^{4}$ \\ Moizs Mariann dr. ${ }^{5}$. Bajzik Gábor $\mathrm{dr}^{5}{ }^{5}$. Vokó Zoltán dr. ${ }^{1,2}$ \\ ${ }^{1}$ Syreon Kutatóintézet Kft., Budapest \\ ${ }^{2}$ Semmelweis Egyetem, Egészségügyi Technológiaértékelő és Elemzési Központ, Budapest \\ ${ }^{3}$ Eötvös Loránd Tudományegyetem, Szociológia Doktori Iskola, Budapest \\ ${ }^{4}$ Országos Korányi Pulmonológiai Intézet, Budapest \\ ${ }^{5}$ Somogy Megyei Kaposi Mór Oktató Kórház, Kaposvár
}

Bevezetés: Korábbi vizsgálatunk szerint a kis dózisú komputertomográfiával évente végzett tüdőrákszürés 50-74 éves dohányzók körében költséghatékony, és az 55-74 évesek körében költségmegtakarító.

Célkitüzés: Ennek a vizsgálatnak a célja a korábbi hosszú távú költséghatékonysági elemzés kiegészítése egy finanszírozó szempontú, rövid és középtávú költségvetési hatásvizsgálattal.

Módszer: Egészség-gazdaságtani modellünk az 50-74 éves, naponta dohányzó lakosság tüdőrákszűrésének költségét hasonlítja össze a szervezett szưrésben nem részesülő, naponta dohányzó lakosság költségével. Ehhez megvizsgáljuk a célpopuláció létszámának alakulását, az eredményes elérés és felfedezés valószínűségét, továbbá a szürés nyomán felmerülő terápiás költségeket és megtakarításokat. A szưrés és a kivizsgálások után diagnosztizált betegek útját az érvényben lévő hazai ellátási protokollnak megfelelően követjük. A kezelések eredményességét a HUNCHEST-felmérés adatai alapján, a kezelésekhez tartozó beavatkozások költségét közfinanszírozási adatok alapján számoljuk. Eredmények: A kis dózisú komputertomográfiával történő tüdőrákszűrés az érintett lakosság 10\%-ának várható részvétele mellett a kezdeti évben mintegy 3,3 milliárd, az 5. évben 1,9 milliárd Ft éves többletkiadással jár. A 3. évig szüréssel felfedezett betegek terápiája többe kerül, mint a szürés nélkülieké, ugyanakkor a 4. és 5 . évben a szürés nélküli csoportban a későbbi stádiumban felismert betegek kezelési költsége már meghaladja a szưrt betegek terápiás költségét. A 3. évtől folyamatosan növekvő terápiás megtakarítás a teljes szűrés költségét a 10. évre az l. év kiadásának $20 \%$-ára csökkenti.

Következtetések: A kis dózisú komputertomográfiával történő tüdőrákszűrés bevezetése évi 2,6 milliárd Ft többletforrást igényelne, és folyamatos kiadáscsökkenés mellett hosszú távon akár nettó megtakarítást is eredményezhet a nem szervezett szûréshez képest. A kockázati csoportok pontosítása, például kiemelt földrajzi területeken végzett célzott szưrés tovább javíthatja az eredményeket.

Orv Hetil. 2021; 162(24): 952-959.

Kulcsszavak: tömeges szűrés, tüdőrák, kis dózisú komputertomográfia, gazdasági értékelés, költségelemzés

\section{The budget impact of lung cancer screening with low-dose computed tomography}

Introduction: Our earlier analysis indicated that screening lung cancer patients with low-dose computed tomography amongst smokers between age of 50-74 and between age of 55-74 is cost-effective and cost-saving, respectively.

Objective: This study aims to extend the long-term cost-effectiveness analysis with short- and mid-term budget impact analysis.

Method: The health economic model compares the cost of nationwide screening amongst smokers between 50-74 years to the current occasional screening policy. The analysis determines the size of the target population, recruitment rates and market uptake. Health care finance costs associated with the patient pathways are determined by national guidelines and clinical practice. Screening and treatment effectiveness are based on the HUNCHEST survey and international scientific literature, while the cost of health states and events are determined using national tariffs. 
Results: Assuming 10\% uptake of low-dose computed tomography screening for the target population will cost an additional 3.3 billion HUF and 1.9 billion HUF in the 1 st and 5th years, respectively. Until the 3rd year, new patients' treatment costs exceed costs due to late discovery and delay in treatment. This pattern is changing from the 4 th year on. Due to timely care savings by the $10^{\text {th }}$ year in the screened population will reduce total costs to the $20 \%$ of the first year costs.

Conclusions: Introduction of national screening for lung cancer patients with low-dose computed tomography is estimated to cost around additional 2.6 billion HUF/year and could end up in net savings in the long run. Identification of risk groups according to regional or other strata could increase the effectiveness and efficiency of the program.

Keywords: mass screening, lung cancer, low-dose computed tomography, economic evaluation, cost analysis

Nagy B, Szilbehorn L, Kerpel-Fronius A, Moizs M, Bajzik G, Vokó Z. [The budget impact of lung cancer screening with low-dose computed tomography]. Orv Hetil. 2021; 162(24): 952-959.

(Beérkezett: 2020. október 27.; elfogadva: 2020. december 16.)

\section{Rövidítések}

$\mathrm{CT}=$ (computed tomography) számítógépes tomográfia; ELEF = Európai Lakossági Egészségfelmérés; HBCS $=$ Homogén Betegségcsoportok Rendszere; HUNCHEST = tüdőrákszûrő program; LDCT $=($ low-dose CT $)$ kis dózisú CT; NLST $=($ National Lung Screening Trial $)$ Nemzeti Tüdőszúrési Vizsgálat; OENO = Orvosi Eljárások Nemzetközi Osztályozása

Az Egészségügyi Világszervezet Nemzetközi Rákkutató Ügynökségének adatbázisa szerint 2018-ban Magyarország világelső volt mind a tüdőrák incidenciája, mind mortalitása terén: 56,7 új megbetegedés és 44,4 haláleset jutott 100000 lakosra [1,2]. A Nemzeti Egészségügyi Alapkezelőnél 2011 és 2016 között évente 69967158 új esetet és 6045-6465 halálesetet jelentettek [3]. A betegség 5 éves, korra standardizált túlélési aránya Magyarországon átlagosan 17,9\% [4], de ezt erősen befolyásolhatja a betegség diagnóziskori súlyossága: lokalizált betegségben $52 \%$, regionálisan kiterjedt betegségben $24 \%$, míg metasztatikus stádiumban mindössze $4 \%$ az 5 éves túlélési arány [5]. A korai stádiumban felfedezett, operált betegek prognózisa sokkal kedvezóbb, ötéves túlélésük elérheti a 60-70\%-ot [6]. Előrehaladott stádiumban viszont a tüdőrák ritkán gyógyítható: késői diagnózis esetén a betegség gyors és agresszív lefolyású, és a halálozási ráta rendkívül magas [7].

A sebészi, kemoterápiás, radioterápiás és legújabban a biológiai készítményekkel történő kezelések folyamatos előretörése ellenére a halálozás csökkentésének legfontosabb lehetősége még mindig a szưróvizsgálattal történő korai felismerés, majd kezelés. A hagyományos mellkasi röntgenfelvétellel történő szúrés hatásossága az irodalmi adatok szerint egyértelmúen gyenge: nem csökkenti a mortalitást a nem szúrt csoporthoz képest [8-10]. Ennek alternatívája a kis dózisú komputertomográfiával (LDCT) történő szûrés, amelynek eredményességét több nemzetközi tanulmány is alátámasztja [10-17].

Az Egyesült Államokban a National Lung Screening Trial (NLST) [10] és annak gazdasági értékelése [18] alapján a magas kockázatúak - kor és dohányzás alapján - LDCT-vel történő szűrését ajánlják és végzik [19]. A lassabban és óvatosabban reagáló Európában is vizsgálják az LDCT-vel történő szúrés elindítását [20], de az egészség-gazdaságtani elemzések száma egyelőre kevés, és további vizsgálatok elvégzését javasolják $[5,21]$. Ezeknél a vizsgálatoknál nagy hangsúlyt kaphat a magas kockázatú szűrési csoportok, a szűrési intervallumok, a pozitív diagnózis és a későbbi betegutak pontos meghatározása [22].

Magyarországon az LDCT-vel történő tüdőrákszưrés vizsgálata két programban indult el. A kaposvári munkacsoport 2012. november 18. és 2014. július 12. között 358 betegnél végezte Magyarország első LDCT-pilotprojektjét; az eredményeket Magyarországon először Moizs és mtsai közölték az Orvosi Hetilapban [23]. A Korányi Intézet vezetésével 2014-ben induló HUNCHEST-vizsgálat első fázisában 2000 beteg vizsgálata után 95 gyanús és 25 megerősített esetet sikerült azonosítani. A szúrési program 2019-tôl 10 centrum bevonásával folytatódik, és 2020 végére 3000 dohányzó adataival frissült [4]. Ezzel párhuzamosan zajlik a fentebb említett Somogy Megyei Kaposi Mór Oktató Kórház tüdőrákszűrési programja, melyben az első fázis során 358 ember közül 5 beteget sikerült kiemelni, és 2020 végéig még több száz szűrést végeztek el. Az egészséggazdaságtani vizsgálatok tervezése 2017-ben a korábban említett centrumok és a Syreon Kutatóintézet szakmai együttmúköódésével indult [24]. Az első, először nemzetközi [25], később magyar adatokkal is feltöltött [26] egészség-gazdaságtani modell eredményeit több konferencián is bemutattuk. Ezek szerint az LDCT-vel évente végzett tüdőrákszürés az 50-74 éves dohányzók körében költséghatékony (azaz a szûrés társadalmilag elfogadható többletköltséggel jár a nem szüréshez képest), sőt az 55-74 évesek körében költségmegtakarító (azaz a szû́rés megtakarítást eredményez). Fontos hangsúlyozni, hogy a modell az érkező adatok tükrében folyamatosan frissül és pontosodik. 
A költséghatékonysági vizsgálatok a „Megéri-e szűrni?" kérdésre adnak választ, míg a költségvetési hatásvizsgálatok a megengedhetőség, azaz a „Mennyit költhetünk szűrésre?” kérdésre válaszolnak. Mindkét kritérium elengedhetetlen feltétele a programok finanszírozásáról hozott társadalmi döntésnek, az LDCT-vel végzett tüdőrákszürés esetében pontosan arról, hogy a jelenleg zajló szürőprogramokat érdemes-e folytatni, illetve kiterjeszteni.

Ennek a vizsgálatnak a célja a korábbi költséghatékonysági elemzések $[25,26]$ kiegészítése egy költségvetési hatásvizsgálattal. Gazdasági hatásmodell segítségével vizsgáljuk az LDCT-vel történő szürővizsgálat országos kiterjesztésének várható költségeit: orvosi, epidemiológiai és egészség-gazdaságtani szempontok alapján számoljuk a finanszírozói költségek alakulását különböző intézkedési szcenáriók esetén.

\section{Módszer}

A költségvetési hatásmodell az érintett lakosság számbavétele, a szưrés gyakorisága és a betegek várható életútja alapján számolja a program éves közfinanszírozói költségét legfeljebb 10 éves időtávon. Az alapmodellben az 50-74 éves, naponta dohányzó lakosság szürését hasonlítjuk össze a szervezett szưrésben nem részesülő, naponta dohányzó lakossággal - az utóbbi a jelenlegi magyarországi helyzetet tükrözi. A kohorszok becsléséhez kiindulópontunk a Központi Statisztikai Hivatal népességprojekciója (Magyarország népességének nemenkénti
1. táblázat |Az LDCT-vizsgálat után azonosított betegek követővizsgálatai nak költsége

\begin{tabular}{lccc}
\hline Beavatkozás & $\begin{array}{c}\text { A diagnosztizált } \\
\text { betegek aránya }\end{array}$ & $\begin{array}{c}\text { Egységár } \\
(\mathrm{Ft})\end{array}$ & $\begin{array}{c}\text { Teljes átlagos } \\
\text { költség }(\mathrm{Ft})\end{array}$ \\
\hline Hasi CT & $39 \%$ & 31850 & \\
Mellkasi CT & $52 \%$ & 31850 & \\
$\begin{array}{l}\text { Bronchoszkópia / } \\
\text { mintavétel / légzésfunkció }\end{array}$ & $64 \%$ & 11022 & 44067 \\
$\begin{array}{l}\text { Transthoracalis túbiopszia } \\
\text { (CT-vezérelt is) }\end{array}$ & $27 \%$ & 29738 & \\
\hline
\end{tabular}

A jelzett beavatkozások tartalmazzák a beavatkozással járó egyéb járulékos vizsgálati költségeket is, mint labor, mintavétel és követődiagnosztika (mellkasröntgen).

Forrás: szakértői konzultációk [29-31].

$\mathrm{CT}$ = számítógépes tomográfia; $\mathrm{LDCT}=$ kis dózisú $\mathrm{CT}$

korösszetétel-változása 1870-től 2060-ig) [27], illetve az Európai Lakossági Egészségfelmérésből (ELEF) ismert, nemek és korcsoportok szerinti dohányzás prevalenciája volt [28]. A 2021-re prognosztizált célpopulációt az 50-74 év közötti összes dohányzó alkotja, akiket 75. életévük betöltéséig évente szưrnek. A szürésben részt vevő populációhoz minden évben csatlakoznak az 50. életévüket betöltött dohányzók, és a kohorszból kikerülnek a 75 év felettiek. Az évente új belépóket minden esetben a vizsgálati időtáv végéig vagy halálukig követi a modell, mely idő alatt rögzíti a felmerült költségeiket.

2. táblázat |A tüdőrákkal diagnosztizált és kezelésre indikált betegek költsége kezelési típusonként

\begin{tabular}{|c|c|c|c|c|}
\hline Kezelési típus & Beavatkozás & $\begin{array}{c}\text { Kezelési típusonkénti } \\
\text { beavatkozások megoszlása }\end{array}$ & Egységár (Ft) & Teljes havi költség $(\mathrm{Ft})$ \\
\hline Reszekció & Mútét & $100 \%$ & 559021 & 559021 \\
\hline Reszekció és adjuváns terápia & Mütét & $100 \%$ & 559021 & 559021 \\
\hline \multirow[t]{3}{*}{ Adjuváns terápia követőköltsége } & Kemoterápia & $70 \%$ & 1646017 & 1877590 \\
\hline & Radioterápia & $5 \%$ & 500000 & \\
\hline & Kemoradioterápia & $25 \%$ & 2801512 & \\
\hline \multirow[t]{3}{*}{ Neoadjuváns terápia és reszekció } & Kemoterápia & $100 \%$ & 840997 & 1431868 \\
\hline & Mellkasi CT & $100 \%$ & 31850 & \\
\hline & Mútét & $100 \%$ & 559021 & \\
\hline \multirow[t]{3}{*}{ Nem mútött betegek } & Kemoterápia & $67,98 \%$ & 727516 & 656863 \\
\hline & Radioterápia & $20,57 \%$ & 500000 & \\
\hline & Kemoradioterápia & $11,44 \%$ & 519648 & \\
\hline Nem műthető betegek szupportív kezelése & Kórházi hospice & $100 \%$ & 376200 & 367200 \\
\hline Mütét után, nincs tüdőrák & CT 3 havonta & $100 \%$ & 31850 & 10617 \\
\hline \multirow[t]{4}{*}{ Mútét utáni progresszió } & Kemoterápia & $40,92 \%$ & 727516 & 546209 \\
\hline & Radioterápia & $6,89 \%$ & 500000 & \\
\hline & Kemoradioterápia & $12,38 \%$ & 519648 & \\
\hline & Szupportív kezelés & $39,80 \%$ & 376200 & \\
\hline
\end{tabular}

Forrás: szakértői konzultációk [29-32].

CT = számítógépes tomográfia 


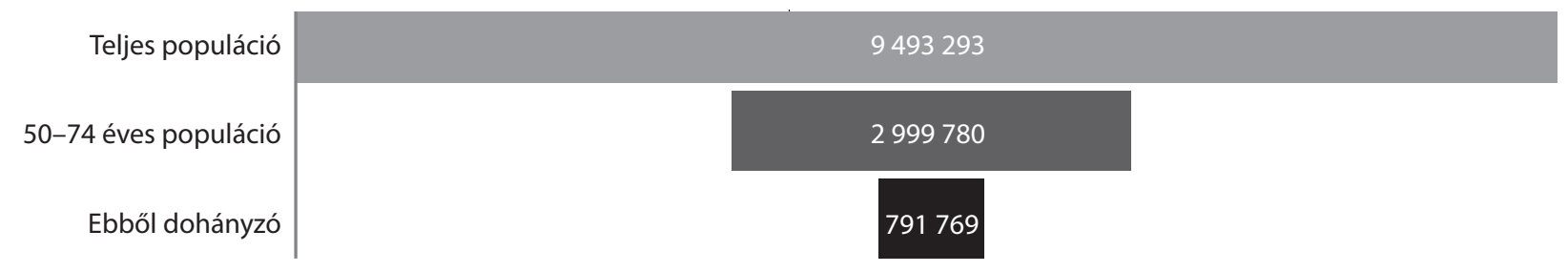

1. ábra $\quad$ A kiinduló populáció meghatározása

A kampányszerü behíváshoz 2 elsőbbségi levelezőlap és normál méretü, „postakész” boríték árával számoltunk, ennek költsége behívott személyenként évente 600 Ft. A szűrővizsgálat költségét két diagnosztikai központ (Affidea, Medicover) árai alapján 20000 Ft értékben határoztuk meg. Az LDCT-vel történt szűrés után pozitívnak bizonyuló személyek kivizsgálásának átlagos költsége további $44067 \mathrm{Ft}$, melyet az 1. táblázatban látható beavatkozások egységárai és a szúréssel azonosított betegek közötti előfordulásaik súlyozott átlagaként számoltunk. Az egységárak minden esetben az egyes beavatkozások OENO-kódjához tartozó pontértékek és az egy pontra jutó 1,98 Ft szorzatai [29-31].

A szűrés és a kivizsgálások után diagnosztizált betegek az érvényben lévő hazai ellátási protokoll betegútjainak megfelelő $[25,26]$ kezelést kapnak. A kezelések eloszlását a HUNCHEST-felmérés adatainak elemzése alapján határoztuk meg. A különböző kezelésekhez tartozó beavatkozásokat, ezek egységárait, arányát és az ezek súlyozott átlagaként számított havi költségeket, valamint a mütéti kezelés után felmerülő egyéb költségeket a 2. táblázat mutatja [29-32], amelyben a fentebb már bemutatott OENO-kódok után járó térítések számítása mellett a HBCS-kódokhoz tartozó pontértékek és az egy pontra jutó 198000 Ft szorzatait használtuk. Az arány az adott kezelési típushoz tartozó betegek eloszlását jelenti, amelyet szakértői becsléssel állapítottunk meg. Eredményes mütét után csupán monitorozási költséggel, mưtét utáni progresszió esetén további terápiákkal számoltunk.

Alapesetben 5 éves elemzési időtávval számoltunk, de a 10 éves kifutást is megvizsgáltuk. Azt feltételeztük, hogy a célpopuláció $10 \%$-a vesz részt sikeresen a szúrésen - őket sikerül elérni, behívni és szükség esetén visszahívni; továbbá az első szürésre eljutó betegek a követőévekben is elmennek a szürésre, tehát nincs lemorzsolódás az évek során, ezek a betegek évről évre megfordulnak a rendszerben. Az eredmények robusztusságának vizsgálatára kétutas érzékenységvizsgálatokat készítettünk, melyek a behívás költsége és eredményessége szerinti 5 éves költségeket becsülték. Az LDCT-vizsgálatok finanszírozói szempontból optimális árának meghatározására küszöbérték-elemzést készítettünk.

\section{Eredmények}

A modell a 2021-ben életben lévő 50-74 év közötti teljes populációból indul ki, melynek nagysága 2999780 fó [27]. Ezek közül a dohányzó populáció az ELEF ne- mek és korcsoportok szerinti dohányzásprevalenciájával [28] számolva 791769 fó. A kiinduló célpopuláció alakulását az 1. ábra mutatja.

Az így induló populáció, valamint a modellbe a további években újonnan belépő (az 50. életévet az adott évben betöltött dohányzó) populáció létszámát és azok évenkénti alakulását a 3. táblázat tartalmazza.

Az évente szürt és a szưrés nélküli populáció éves költségeit a 4. táblázat szemlélteti. A kezdeti évben mintegy 3,3 milliárd Ft, az 5. évben 1,9 milliárd Ft éves többletköltséggel jár az LDCT-vel történő tüdőrákszűrés az érintett lakosság 10\%-os részvétele mellett. A szüréssel kapcsolatos közvetlen többletköltségek évente nagyjából 2,6 milliárd Ft-ot tesznek ki. Szürés esetén a 3. évig az újonnan felfedezett betegek terápiája többe kerül, mint a szưrés nélkülieké. Ugyanakkor a 4. és 5. évben a szürés nélküli csoportban a későbbi stádiumban felismert, drágábban és kevésbé eredményesen kezelt betegek költsége már meghaladja a szürt betegek terápiás költségét.

A 2. ábra mutatja a költségek 10 éves alakulását. Látható, hogy a 3. évtől folyamatosan növekszik a terápiás megtakarítás, a teljes szưrés költsége a 10. évben az első év költségeinek 20\%-ára csökken. A 10. évben a szúrési program költségszaldója így várhatóan 635 millió Ft lenne, a teljes forráskiáramlás a program 10 éve alatt 19 milliárd Ft. A küszöbérték-elemzés megmutatta, hogy az LDCT-vizsgálat 11567 Ft-os egységára mellett a 10. évtől megtakarítás realizálható. A 11567 Ft-os egységár a jelenlegi natív mellkasi CT pontértékéhez ( 10056 Ft) közelítő összeg.

A behívás költségének és a betegek elérésének a költségvetésre gyakorolt hatását az 5. táblázat kétutas érzékenységelemzése mutatja. A finanszírozó nettó költsége az elérés drágulásával (300-450-600-3000-6000Ft-os

\begin{tabular}{|c|c|c|c|c|c|}
\hline \multirow{2}{*}{$\begin{array}{l}\text { 3. táblázat } \\
\text { Modellév } \rightarrow\end{array}$} & \multicolumn{5}{|c|}{$\begin{array}{l}\text { A szúrópprogramba évente frissen belépók létszáma és évenkénti } \\
\text { alakulása* }\end{array}$} \\
\hline & 2021 & 2022 & 2023 & 2024 & 2025 \\
\hline \multicolumn{6}{|l|}{ Kezdő év $\downarrow$} \\
\hline 2021 & 791769 & 764111 & 731150 & 698908 & 667675 \\
\hline 2022 & & 48814 & 47109 & 45077 & 43089 \\
\hline 2023 & & & 49458 & 47730 & 45671 \\
\hline 2024 & & & & 50025 & 48278 \\
\hline 2025 & & & & & 59221 \\
\hline
\end{tabular}

*A költséghatékonysági modell túlélésével számolva. 
4. táblázat |Az évente elvégzett szúrés és a jelenlegi helyzet (nincs szervezett szürés) teljes finanszírozói költségeinek összehasonlítása éves bontásban

\begin{tabular}{|c|c|c|c|c|c|}
\hline Évenkénti szűrés & 2021 & 2022 & 2023 & 2024 & 2025 \\
\hline Behívás (eFt) & 475061 & 475206 & 476167 & 477156 & 483717 \\
\hline Szúrés és dg. (eFt) & 1971638 & 1747289 & 1724386 & 1713294 & 1730334 \\
\hline Kezelés (eFt) & 10164812 & 26491694 & 32211358 & 35350498 & 37388868 \\
\hline ÖSSZESEN & 12611511 & 28714190 & 34411911 & 37540948 & 39602918 \\
\hline Nincs szervezett szűrés & 2021 & 2022 & 2023 & 2024 & 2025 \\
\hline Behívás (eFt) & 0 & 0 & 0 & 0 & 0 \\
\hline Szürés és dg. (eFt) & 0 & 0 & 0 & 0 & 0 \\
\hline Kezelés (eFt) & 9325467 & 25518972 & 31836682 & 35420467 & 37709639 \\
\hline ÖSSZESEN & 9325467 & 25518972 & 31836682 & 35420467 & 37709639 \\
\hline Költségkülönbség & 2021 & 2022 & 2023 & 2024 & 2025 \\
\hline Behívás (eFt) & 475061 & 475206 & 476167 & 477156 & 483717 \\
\hline Szû́rés és dg. (eFt) & 1971638 & 1747289 & 1724386 & 1713294 & 1730334 \\
\hline Kezelés (eFt) & 839346 & 972723 & 374676 & -69969 & -320771 \\
\hline ÖSSZESEN & 3286045 & 3195219 & 2575228 & 2120481 & 1893279 \\
\hline
\end{tabular}

Az értékek ezer Ft-ban értendők.

dg. = diagnózis

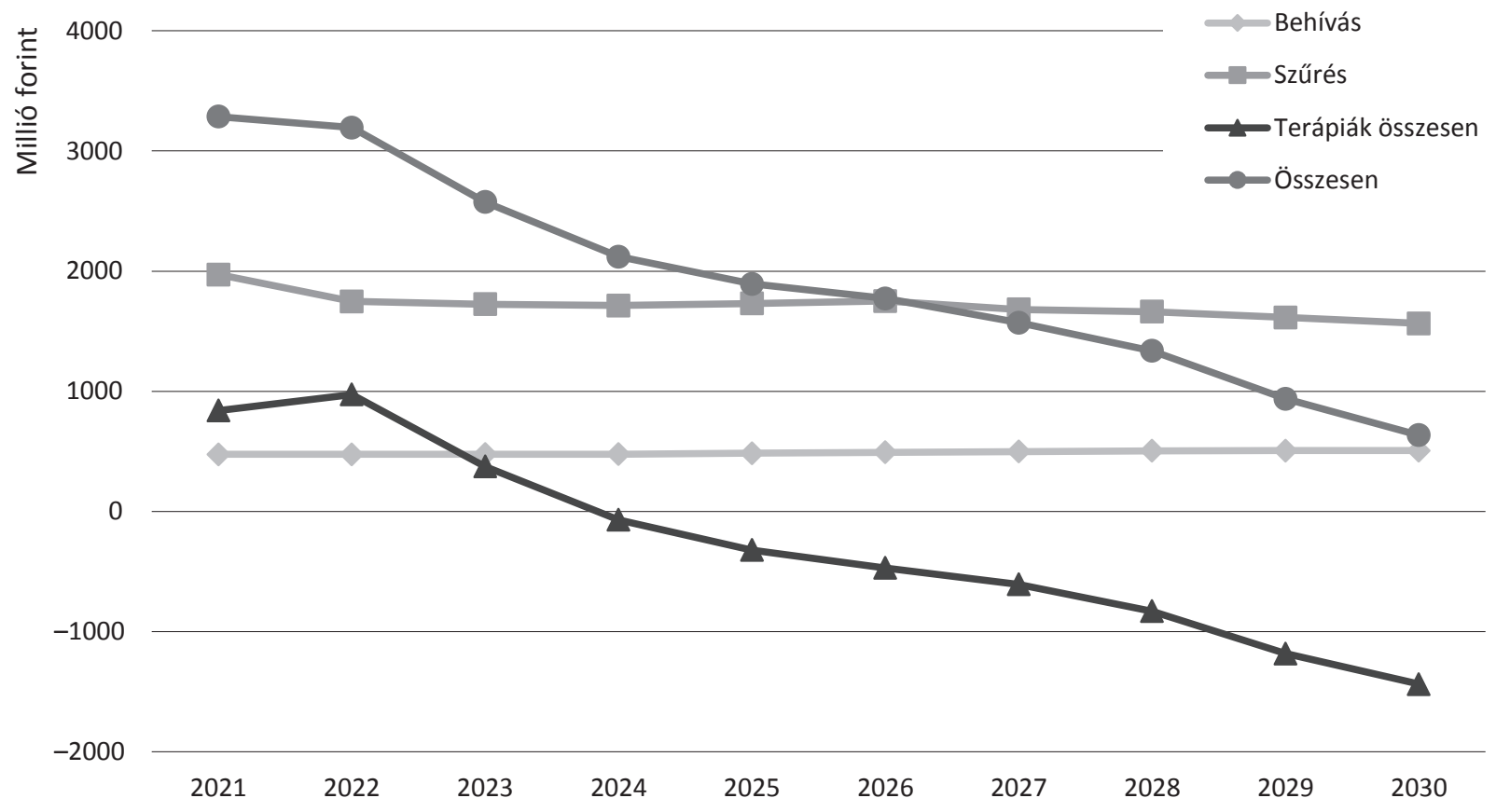

2. ábra | Az LDCT-vel végzett tüdőrákszưrés nettó költségeinek 10 éves alakulása

'postaköltség'), illetve az elért lakosság arányának növekedésével (1-5-10-20-25\%-os elérés) együtt emelkedik. Amennyiben az elérés költsége a jelenlegi összeg ötszörösére $(3000 \mathrm{Ft})$ növekszik, és a célpopuláció 25\%-át sikerül elérni, akkor az 1. évben 9,4 milliárd Ft-ot, az 5. évben 38,6 milliárd Ft-ot (azaz évente átlagosan 7,7 milliárd Ft-ot) kell fizetni. Ugyanakkor kisebb postai költségek mellett $(450 \mathrm{Ft})$ és kevésbé sikeres eléréssel $(5 \%)$ a program többletköltsége az 1 . évben 1,8 milliárd Ft és 5 év alatt összesen 7,1 milliárd Ft (1,4 milliárd Ft/év). 
5. táblázat |A betegek elérésének és a behívás költségének kétutas érzékenységelemzése

\begin{tabular}{|c|c|c|c|c|c|}
\hline \multicolumn{6}{|l|}{ Az első év nettó költsége } \\
\hline A betegek elérése $(\%) \rightarrow$ & $1 \%$ & $5 \%$ & $10 \%$ & $20 \%$ & $25 \%$ \\
\hline \multicolumn{6}{|l|}{ A behívás költsége $(\mathrm{eFt}) \downarrow$} \\
\hline 300 & 518629 & 1643022 & 3048514 & 5859498 & 7264989 \\
\hline 450 & 637394 & 1761788 & 3167279 & 5978263 & 7383755 \\
\hline 600 & 756160 & 1880553 & 3286045 & 6097028 & 7502520 \\
\hline 3000 & 2656404 & 3780798 & 5186289 & 7997273 & 9402765 \\
\hline 6000 & 5031710 & 6156104 & 7561595 & 10372579 & 11778071 \\
\hline \multicolumn{6}{|l|}{5 év nettó költsége } \\
\hline A betegek elérése $(\%) \rightarrow$ & $1 \%$ & $5 \%$ & $10 \%$ & $20 \%$ & $25 \%$ \\
\hline \multicolumn{6}{|l|}{ A behívás költsége $(\mathrm{eFt}) \downarrow$} \\
\hline 300 & 2261948 & 6535126 & 11876598 & 22559543 & 27901016 \\
\hline 450 & 2858774 & 7131952 & 12473425 & 23156370 & 28497842 \\
\hline 600 & 3455601 & 7728779 & 13070251 & 23753196 & 29094669 \\
\hline 3000 & 13004827 & 17278005 & 22619477 & 33302422 & 38643895 \\
\hline 6000 & 24941359 & 29214537 & 34556009 & 45238954 & 50580427 \\
\hline
\end{tabular}

Az eredmények ezer forintban értendők.

\section{Megbeszélés}

Vizsgálatunk a HUNCHEST első eredményeit használó költséghatékonysági modell [24, 25] paramétereit használva méri fel az LDCT-tüdőrákszűrés várható hatását a közfinanszírozó költségvetésére. Ötéves időtávon - amely a finanszírozó szempontjából közép-, egy megelőzési program szempontjából rövid távnak értékelhető - évi 3,3-1,9 milliárd Ft-os költségkiáramlással lehet számolni. Ez az összeg a sikeresen elért populáció és a behívási költségek fényében jelentősen változhat - nőhet, de akár csökkenhet is. Eredményeink finomítják Moizs és mtsai korábbi becslését, amely szerint a 40 év feletti dohányosok LDCT-tüdőrákszürésen való részvétele mellett a finanszírozó éves költsége jelentős összeggel, 3,53 milliárd Ft-tal növekedne [33]. Más országok vizsgálatai is rövid távú költségnövekedésről számolnak be [34-36]. A modellben tízéves időtávon - amely a finanszírozó szempontjából hosszú, de egy megelőzési program szempontjából középtávnak tekinthető - a finanszírozói terhek fokozatosan csökkennek, és a 10. évben a program az első év költségeinek $20 \%$-ával, azaz 630 millió Ft többletkiadással jár. Ezekkel az eredményekkel összhangban van, és a prevenciós program kiadási dinamikáját jól mutatja korábbi költséghatékonysági vizsgálatunk, mely szerint teljes emberöltőt tekintve az 55-74 éves dohányzók között elvégzett éves szúrés költségmegtakarítással jár. Tíz évnél hosszabb költségvetési időtáv a prevenciós programok szempontjából reális, ugyanakkor a finanszírozó szempontjából nehezen értelmezhető. Ezt támasztja alá, hogy más prevenciós programok hatása is bevezetésük után jóval később, néha csak egy teljes emberi életöltő dimenziójában jelentkezik [37]. Éppen ezért elengedhetetlen a rövid és hosszú távú költségek és hasznok pontos számbavétele már a program indulásának pillanatában.

Annak ellenére, hogy igyekeztünk minden bizonytalanságot kezelni, vizsgálatunknak vannak korlátai. Modellünk a magyar egészség-gazdaságtani irányelv útmutatását követve nem veszi figyelembe az LDCT-vel végzett szürés járulékos hasznait; ilyen haszonról számolt be például Moizs tanulmánya, mely szerint tüdőrák mellett két további tumoros elváltozást sikerült a szúrés során kiemelni. Másik fontos fejlemény, hogy eredményeink a HUNCHEST-vizsgálat induló szűrési adatain alapszanak, de a második utánkövetésről az elemzés időpontjában még nem állt rendelkezésre elegendő információ. További limitáció, hogy a szûrés eredményességét a teljes HUNCHEST-vizsgálati populáció adataiból számoltuk, holott ezeknek csak nagyjából 50\%-a volt dohányos. A szürés eredményessége csak a dohányzók vizsgálata esetén valószínúleg jobb lenne. A modell azt is feltételezi, hogy az első szürésre eljutó betegek a követőévekben is elmennek a szürésre, tehát nincs „lemorzsolódás”, ami a várható költségek felülbecslését jelentheti. Mindezen bizonytalan tényezők ellenére, jelenlegi tudásunk alapján, kevés esélyt látunk arra, hogy elemzésünk végkövetkeztetése frissített adatok tükrében lényegesen változzon.

Eszerint Magyarországon az LDCT-vel történő tüdőrákszürés bevezetése egészség-gazdaságtani szempontból 50 éves kortól, évenkénti szűréssel várhatóan évi 2,6 milliárd Ft forrást igényel, és a szürés évente történő 
megismétlése mellett a kiadások folyamatos csökkenése várható. A kockázati csoport pontosítása, például kiemelt földrajzi területeken végzett célzott szűrés, ennél akár jobb eredményekre is vezethet.

Anyagi támogatás: Az elemzés és a közlemény az Országos Korányi Pulmonológiai Intézet és a Bolyai János Kutatási Ösztöndíj támogatásával készült.

Szerzői munkamegosztás: A szakmai elemzési terv kialakításában minden szerző részt vett. A klinikai, finanszírozási és betegút-paraméterek kialakítása K.-F. A., M. M. és B. G. szakmai útmutatása alapján történt. Az egészség-gazdaságtani elemzést Sz. L. és N. B. végezte. A projektet N. B. koordinálta, és V. Z. felügyelte. A cikk végleges változatát valamennyi szerző elolvasta és jóváhagyta.

Érdekeltségek: A szerző́knek nincsenek érdekeltségeik.

\section{Irodalom}

[1] GLOBOCAN. Estimated number of new cases in 2018, lung, both sexes, all ages. Available from: https://gco.iarc.fr/today/ online-analysis-table? $\mathrm{v}=2018 \&$ mode $=$ population $\&$ mode_popul ation $=$ countries\&population $=900 \&$ populations $=900 \& \mathrm{key}=\mathrm{asr} \&$ sex $=0$ \& cancer $=15$ \&type $=0$ \& statistic $=5$ \&prevalence $=0$ \&populat ion_group $=0 \&$ ages_group $\% 5 \mathrm{~B} \% 5 \mathrm{D}=0$ \&ages_group $\% 5 \mathrm{~B} \% 5 \mathrm{D}=$ 17 \&group_cancer $=1$ \&include_nmsc $=1$ \&include_nmsc_other $=1$ [accessed: May 12, 2019].

[2] GLOBOCAN. Estimated number of deaths in 2018, lung, both sexes, all ages. Available from: https://gco.iarc.fr/today/online-analysis-table?v=2018\&mode=population\&mode_populati on $=$ countries\&population $=900 \&$ populations $=900 \& \mathrm{key}=$ asr\&se $\mathrm{x}=0$ \& cancer $=15$ \& type $=1$ \&statistic $=5$ \&prevalence $=0$ \&populati on_group $=0$ \&ages_group $\% 5 \mathrm{~B} \% 5 \mathrm{D}=0$ \&ages_group $\% 5 \mathrm{~B} \% 5 \mathrm{D}=$ $17 \&$ group_cancer $=1$ \&include_nmsc $=1$ \&include_nmsc_other $=1$ [accessed: May 12, 2019].

[3] Bogos K, Kiss Z, Gálffy G, et al. Revising incidence and mortality of lung cancer in Central Europe: an epidemiology review from Hungary. Front Oncol. 2019; 9: 1051.

[4] Bogos K, Kiss Z, Gálffy G, et al. Lung cancer in Hungary. J Thorac Oncol. 2020; 15: 692-699.

[5] Puggina A, Broumas A, Ricciardi W, et al. Cost-effectiveness of screening for lung cancer with low-dose computed tomography: a systematic literature review. Eur J Public Health 2016; 26: $168-175$

[6] Kovács G. Risk group chest X-ray for the early detection of lung cancer. [A mellkasi röntgen-szúrővizsgálat jelentősége a tüdőrák korai felismerésében a fokozott rizikójú népességcsoportban.] Orv Hetil. 2008; 149: 975-982. [Hungarian]

[7] Ellis PM, Vandermeer R. Delays in the diagnosis of lung cancer. J Thorac Dis. 2011; 3: 183-188.

[8] Detterbeck FC, Mazzone PJ, Naidich DP, et al. Screening for lung cancer: diagnosis and management of lung cancer, 3rd ed. American College of Chest Physicians evidence-based clinical practice guidelines. Chest 2013; 143(5 Suppl): e78S-e92S.

[9] Moyer VA. Screening for lung cancer: U.S. Preventive Services Task Force recommendation statement. Ann Intern Med. 2014; 160: 330-338.

[10] National Lung Screening Trial Research Team, Aberle DR, Adams AM, Berg CD, et al. Reduced lung-cancer mortality with low-dose computed tomographic screening. N Engl J Med. $2011 ; 365$ : 395-409.

[11] Becker N, Motsch E, Gross ML, et al. Randomized study on early detection of lung cancer with MSCT in Germany: results of the first 3 years of follow-up after randomization. J Thorac Oncol. 2015; 10: 890-896.

[12] Field JK, Duffy SW, Baldwin DR, et al. The UK Lung Cancer Screening Trial: a pilot randomised controlled trial of low-dose computed tomography screening for the early detection of lung cancer. Health Technol Assess. 2016; 20: 1-146.

[13] Infante M, Cavuto S, Lutman FR, et al. Long-term follow-up results of the DANTE trial, a randomized study of lung cancer screening with spiral computed tomography. Am J Respir Crit Care Med. 2015; 191: 1166-1175.

[14] Paci E, Puliti D, Lopes Pegna AL, et al. Mortality, survival and incidence rates in the ITALUNG randomised lung cancer screening trial. Thorax 2017; 72: 825-831.

[15] Sverzellati N, Silva M, Calareso G, et al. Low-dose computed tomography for lung cancer screening: comparison of performance between annual and biennial screen. Eur Radiol. 2016; 26: 3821-3829.

[16] van Klaveren RJ, Oudkerk M, Prokop M, et al. Management of lung nodules detected by volume CT scanning. N Engl J Med. 2009; 361: 2221-2229.

[17] Wille MM, Dirksen A, Ashraf H, et al. Results of the randomized Danish lung cancer screening trial with focus on high-risk profiling. Am J Respir Crit Care Med. 2016; 193: 542-551.

[18] Black WC, Gareen IF, Soneji SS, et al. Cost-effectiveness of CT screening in the National Lung Screening Trial. N Engl J Med. 2014; 371: 1793-1802.

[19] Wood DE, Kazerooni EA, Baum SL, et al. Lung cancer screening, version 3.2018, NCCN clinical practice guidelines in oncology. J Natl Compr Canc Netw. 2018; 16: 412-441.

[20] Oudkerk M, Devaraj A, Vliegenthart R, et al. European position statement on lung cancer screening. Lancet Oncol. 2017; 18: e754-e766.

[21] Azar FE, Azami-Aghdash S, Pournaghi-Azar F, et al. Cost-effectiveness of lung cancer screening and treatment methods: a systematic review of systematic reviews. BMC Health Serv Res. 2017; 17: 413 .

[22] Raymakers AJ, Mayo J, Lam S, et al. Cost-effectiveness analyses of lung cancer screening strategies using low-dose computed tomography: a systematic review. Appl Health Econ Health Policy 2016; 14: 409-418.

[23] Moizs M, Bajzik G, Lelovics Zs, et al. Preliminary experiences with low-dose computed tomography for lung cancer screening in Hungary. [Alacsony dózisú CT-vel történő tüdőrákszúrés magyarországi bevezetésének első tapasztalatai.] Orv Hetil. 2014; 155: 383-388. [Hungarian]

[24] Vokó Z, Barra M, Molnár A, et al. Model concept of the health economic evaluation of low-dose CT lung cancer screening in Hungary. [Az alacsony dózisú CT-vel végzett tüdőrákszúrés magyarországi egészség-gazdaságtani elemzésének koncepcionális terve.] Orv Hetil. 2017; 158: 963-975. [Hungarian]

[25] Molnár A, Nagy B, Kerpel-Fronius A, et al. Modelling patient pathways of low-dose computed tomography screening for lung cancer in Hungary. Value Health 2017; 20: A750.

[26] Vokó Z, Molnár A, Válay V, et al. Cost-effectiveness analysis of low-dose computed tomography screening for lung cancer in Hungary. Eur J Public Health 2019; 29: ckz186.293.

[27] Hungarian Central Statistical Office. Population of Hungary by sex and age, l January. [Központi Statisztikai Hivatal. Magyarország népességének száma nemek és életkor szerint, január 1.] Központi Statisztikai Hivatal, Budapest, 2020. [Hungarian]

[28] Hungarian Central Statistical Office. Health Survey 2009. [Központi Statisztikai Hivatal. Egészségfelmérés (ELEF), 2009.] Statisztikai Tükör 2010; 4(50). [Hungarian] 
[29] Ministry of National Resources. 11/2012 (II. 28.) decree on anti-cancer therapies financed from the Health Insurance Fund according to homogeneous disease groups 959A-L and 9511-9515. [11/2012. (II. 28.) NEFMI rendelet az Egészségbiztosítási Alapból a 959A-L, valamint 9511-9515 homogén betegségcsoportok szerint finanszírozott daganatellenes terápiákról.] Magy Közl. 2012; 23: 4093-5097. [Hungarian]

[30] Ministry of Welfare. 9/1993 (IV. 2.) NM decree on certain issues of the social security financing of health care. $[9 / 1993$. (IV. 2.) NM rendelet az egészségügyi szakellátás társadalombiztosítási finanszírozásának egyes kérdéseiről.] https://net.jogtar. hu/jogszabaly?docid=99300009.nm [Hungarian]

[31] Ministry of Human Resources and Ministry of National Economy. Joint statement of the Minister of Human Resources and the Minister of National Economy on the forint value of inpatient and outpatient specialist care units. [EMMI és NGM. Az emberi erőforrások minisztere és a nemzetgazdasági miniszter együttes közleménye a fekvő- és járóbeteg-szakellátás teljesítményegységeinek forintértékéról.] Eü Közl. 2017; 21: 3767. [Hungarian]

[32] Ostoros G. Lung cancer. [Tüdőrák.] Korányi Bull. 2017; 1: 32 40. [Hungarian]

[33] Moizs M. The situation and new possibilities of lung cancer screening in Hungary using low-dose CT imaging. PhD Thesis.
University of Debrecen, Doctoral School of Health Sciences. [A tüdőrákszűrés magyarországi helyzete és új lehetôségei alacsony sugárdózisú CT-képalkotás alkalmazásával. PhD-értekezés.] Debreceni Egyetem, Egészségtudományi Doktori Iskola, Debrecen, 2015. [Hungarian]

[34] Evans WK, Flanagan WM, Miller AB. Implementing low-dose computed tomography screening for lung cancer in Canada: implications of alternative at-risk populations, screening frequency, and duration. Curr Oncol. 2016; 23: e179-e187.

[35] Goulart BH, Bensink ME, Mummy DG, et al. Lung cancer screening with low-dose computed tomography: costs, national expenditures, and cost-effectiveness. J Natl Compr Canc Netw. 2012; 10: 267-275.

[36] Roth JA, Sullivan SD, Ravelo A, et al. Low-dose computed tomography lung cancer screening in the Medicare program: Projected clinical, resource, and budget impact. J Clin Oncol. 2014; 32(15_Suppl): 6501 .

[37] Vokó Z, Kaló Z. Prevention - expenditure - effectiveness. [Prevenció - kiadások - hatékonyság.] Eü Gazd Szle. 2012; 50(1): 6-8. [Hungarian]

(Nagy Balázs dr., Budapest, Mexikói út 65/A, 1142 e-mail: balazs.nagy@syreon.eu)

\section{"Neglecta solent incendia sumere vires." (Elhanyagolt lángból támad, s nő nagyra a tűzvész.)}

A cikk a Creative Commons Attribution 4.0 International License (https://creativecommons.org/licenses/by/4.0/) feltételei szerint publikált Open Access közlemény, melynek szellemében a cikk bármilyen médiumban szabadon felhasználható, megosztható és újraközölhetö, feltéve, hogy az eredeti szerző és a közlés helye, illetve a CC License linkje és az esetlegesen végrehajtott módosítások feltüntetésre kerülnek. (SID_1) 